\title{
HALAL TOURISM IN LOMBOK ISLAND: POTENTIALS, CHALLENGES, AND THE ROLE OF ISLAMIC EDUCATION
}

\author{
MOHAMAD IWAN FITRIANI*, NAZAR NAAMY \\ Universitas Islam Negeri Mataram
}

\section{Abstract}

Although Lombok of West Nusa Tenggara has gained an excellent international reputation for its halal tourism (2015-2018), tourism in the region is not without obstacles. Several elements of the Sasak-Lombok community, for instance, still refuse the concept of halal tourism because it is likely to cause harm to conventional tourism. This article will examine potentials, challenges, and the role of Islamic education in halal tourism in Lombok. It employs a descriptive-qualitative approach, where data collection is obtained from focus group discussions, in-depth interviews, document analysis, and media reporting. Meanwhile, data validity testing is carried out with the triangulation technique. After a profound analysis, this research found that: (1) the potentials for halal tourism in Lombok are made of its natural beauty, cultural distinctiveness, and tradition of the local community predominated by Muslims; (2) the challenges of halal tourism in Lombok include two things: a) conceptual challenges that deal with the absence of terms representing the desires of all parties, and b) practical problems that deal with economic, environmental, social, and cultural matters; (3) Islamic education—as a value, activity, or institution-plays a vital role in disseminating representative concepts for halal tourism acceptable to all parties, i.e. the local community, tourism actors, and government. This acceptance is one of the keys to the successful development of halal tourism in Lombok.

\footnotetext{
* Corresponding author: Jl. Pendidikan No. 35, Dasan Agung Baru, Selaparang, Mataram, Nusa Tenggara Barat, Indonesia, 83125. E-mail: iwanfitriani@gmail.com.
} 
Meskipun Lombok Nusa Tenggara Barat telah mendapatkan reputasi internasional yang baik dalam bidang pariwisata halal (20152018), namun menyisakan problem sosiologis. Sebagian asyarakat Sasak-Lombok, misalnya, masih menolak konsep wisata halal karena kemungkinan akan membahayakan pariwisata konvensional. Artikel ini akan membahas potensi, tantangan, dan peran pendidikan Islam dalam pariwisata halal di Lombok. Penelitian ini menggunakan pendekatan deskriptif-kualitatif, di mana pengumpulan data diperoleh dari kelompok diskusi, wawancara, analisis dokumen, dan pelaporan media. Sementara itu, pengujian validitas data dilakukan dengan teknik triangulasi. Penelitian ini menemukan bahwa: (1) Wisata halal di Lombok terbentuk dari potensi keindahan alam, kekhasan budaya, dan tradisi masyarakat setempat yang didominasi oleh umat Islam; (2) Tantangan pariwisata halal di Lombok meliputi dua hal: a) tantangan konseptual yang berhubungan dengan tidak adanya istilah yang mewakili keinginan semua pibak, dan b) tantangan praktis yang berhubungan dengan masalah ekonomi, lingkungan, sosial, dan budaya; (3) Pendidikan Islam-sebagai nilai, aktivitas, atau lembaga-memainkan peran penting dalam menyebarluaskan konsep-konsep representatif untuk pariwisata halal yang dapat diterima oleh semua pibak, yaitu masyarakat lokal, pelaku pariwisata, dan pemerintah. Penerimaan ini adalah salah satu kunci keberhasilan pengembangan pariwisata halal di Lombok.

Keywords: challenges; halal tourism; Islamic education; Lombok; potentials.

\section{Introduction}

The concept of sharia is adopted not only by Islamic legal discipline $(f i q h)$ but also by other disciplines, such as tourism. The presence of sharia in tourism is a unique and interesting fact to study since the image of tourism tends to be associated with violating of Islamic ethics. Tourism is usually concerned with fun, happiness, and freedom with no consideration to the Islamic teachings. In Lombok of West Nusa Tenggara, for exam- 
ple, many people assume that tourism cannot be separated from the $3 \mathrm{~S}$ culture, i.e. sea, sand, and sex. At the same time, sharia is identical with norms, ethics, values, and regulations based on Islamic teachings. However, some facts also show that the concept of sharia and tourism are related to each other.

When the concept of sharia and tourism are linked, many terms emerge, such as Islamic tourism, halal tourism, halal lifestyle, halal travel, halal-friendly tourism destination, Muslim-Friendly Tourism (MFT), Muslim halal travel destination, universal tourism, and religious tourism. The key idea behind these terms is a tourism that is based on Islamic teachings. In Indonesia, in general, and Lombok-West Nusa Tenggara, in particular, the relationship between sharia and tourism can be found in sharia tourism or halal tourism.

Another interesting fact about sharia tourism is that this type of tourism has been developed in various parts of the world, such as in Russia, Japan, Thailand, New Zealand, Australia, Saudi Arabia, Malaysia, Turkey, and Indonesia. Specifically in Indonesia, one of the regions employing as the sharia tourist destinations is Lombok Island of West Nusa Tenggara. It is in such a framework that this study focuses on sharia tourism in Lombok. In this study, sharia tourism and halal tourism are seen the same and, thus, are used interchangeably.

Sharia tourism in Lombok is interesting to study because the region is a new icon of tourism in Indonesia. The region has a number of potentials. First, Lombok has the potential to be a halal tourist destination. A saying that small is beautiful should match with the condition of Lombok Island. Tourist destinations are found in almost every part of the island which stretches from Mataram in the West to Sembalun in the East (Jaelani 2017). Therefore, it is not surprising when Ahmad Saufi $(2015,9)$ stated that Lombok is beautiful in nature and unique in culture. 
Second, like Bali popular with the island of a thousand temples, Lombok is popular with the island of a thousand mosques. This fact indicates that the majority of Muslims will support the existence of halal tourism. According to Shaufi $(2015,67)$ such a status could be one of the reasons behind the Indonesian Government's plan to develop Lombok as an Islamic, halal-friendly tourist destination in Indonesia.

Third, Lombok recently won a prestigious title named the world best halal destination and world best honeymoon destination in 2015. That achievement continued in the following year as the region won three awards at the World Halal Tourism Award 2016 in Abu Dhabi, UAE. Novotel Lombok Resort \& Villas was awarded as the World's Best Halal Beach Resort. Sembalun won the World's Best Halal Honeymoon Destination Award. And the website www.wonderfullomboksumbawa. com won the World's Best Halal Tourism Website Award (Fitriani 2015, 5). Despite those prestigious achievements, however, many people of Lombok do not understand what sharia tourism or halal tourism means. Many of them have misconceptions on the meaning of halal tourism. They consider that halal tourism is religious tourism. It reflects halal in food alone. It is intended only for Middle-Eastern tourists. Consequently, it is regarded as a Muslim matter only.

Fourth, when halal tourism is very popular among the people of Lombok, the term halāl (lawful) is then opposed to harām (forbidden), so that the existence of halal tourism opposes haram tourism (Fitriani 2015, 5). This notion triggers conflict among some people, especially those who have been comfortable with conventional tourism. Fifth, regulation on halal tourism with reference to Law No. 51 of 2015 or No. 2 of 2015 issued by the West Nusa Tenggara government is still multi-interpreted. It is not clear whether the regulation is compulsory or optional. 
At this point, it is obvious that halal tourism in Lombok is not without obstacles. As stated by the Committee for Economic and Commercial Cooperation of Islamic Corporation Organizations (COMCEC), Indonesia has great potential to develop the Muslim-Friendly Tourism (MFT) market with a variety of tourism products to be developed. Based on the Global Muslim Travel Index (GMTI), Indonesia ranks third after Malaysia and Turkey (Comcec 2016). A number of regions in the country have been designed and developed as halal tourism destinations. There are the top 10 Muslim-friendly destinations, i.e. Aceh, West Sumatra, Jakarta, West Java, Riau and the Riau Islands, Central Java, East Java, the Special Region of Yogyakarta, and Lombok of West Nusa Tenggara. Therefore, this paper will focus only on halal tourism in Lombok because of one main reason. Although the region has been recognized as the world's best halal destination and the best honeymoon destination, many people in Lombok do not understand what halal tourism means.

Studies on sharia tourism have been carried out at the local, national, and international levels. For example, in 2017, Izza Firdausi, Stani Juanita Marantika, Zein Nidaulhaq Firdaus, and Rifqah Sajidah wrote Lombok: Halal Tourism as a New Indonesia Tourism Strategy. Their study focuses on the perspective of sharia tourism as a sub-component of tourism which is subsequently considered a new strategy in tourism. It is descriptive, analytical study about the potential and strategy with an economic perspective (Firdausi et al. 2017). However, the study has not touched the socio-cultural and religious implications of the Sasak-Lombok community.

Furthermore, Andrinata, Sumarmi, and I Komang Astina (2016) wrote Pengembangan Modul Geografi Pariwisata Berbasis Paket Wisata Pulau Lombok Sebagai Upaya Memupuk Rasa Cinta Tanah Air Pada Mahasiswa. Their research is a research 
and development study on the aspect of teaching materials, namely the "Geography Module" dominated by the social science perspective that is associated with patriotism values. Meanwhile, this research uses a qualitative approach involving several viewpoints, not only the social science perspective.

At the international level, researchers who study halal tourism include (1) Mohamed Battour and Mohd Nazari Ismail (2016) on Halal Tourism: Concepts, Practices, Challenges and Future (2) Sulhaini (2015) on Developing Halal Tourist Destinations: Investigating Lombok's Potentials from Destination Marketing Perspective (3) Piyachat Puangniyom, Nantawan Swangcheng, and Tosaporn Mahamud (2010) on Halal Tourism Strategy to Promote Sustainable Cultural Tourism in Thailand; (4) Teoman Duman (2011) on Value of Islamic Tourism Offering: Perspectives from the Turkish Experience, a Paper presented at World Islamic Tourism Forum 2011; (5) NK Gabdrakhmanov (2016) on Problems of Development of Halal Tourism In Russia, and (6) Errid Hadisyah Putra (2016) on Understanding Muslim Customer Satisfaction with Halal Destinations: The Effects of Traditional and Islamic Values.

From the above-mentioned researches, a study about sharia tourism in Lombok, especially in relation to Islamic education, has not been made yet. Islamic education has an essential role in the development of tourism in Lombok of West Nusa Tenggara. It is crucial because, as a value, activity, or institution, it can provide conceptual and practical insight about what is happening. In this case, Islamic education can promote inclusive values in sharia tourism. Although conceptually halal tourism is related to the teachings of Islam, it substantially aims to benefit the ummah. The essence of halal tourism is to bring tourism that provides comfort for the tourists. In this case, Islamic education is expected to be able to give a real contribution, such as UIN 
Mataram that is currently opening a sharia tourism study program. In addition, a strategic management perspective is also needed, such as by conducting an Internal Environmental Analysis (ALI) and External Environment Analysis (ALE). While ALI deals with strengths and weaknesses, ALE is concerned with opportunities and challenges (Wahab 2013).

More specifically, issues to be discussed in this study include: (1) the potentials of halal tourism in Lombok, (2) the challenges of developing halal tourism in Lombok, and (3) the roles of Islamic education in developing halal tourism in Lombok. This research uses a descriptive-qualitative approach with which the researcher wants to have an in-depth understanding related to the ongoing problems (Rahardjo 2013). It is a vital instrument. The informants are determined by purposive sampling or snowball sampling. Data sources will be collected through focus group discussion or peer discussion, in-depth interviews with several key informants, document analysis, and media reporting. Finally, data validity testing is done with the triangulation technique followed with analysis (Hatch 2002; Moleong 2006; Arikunto 2010).

\section{Potentials of Halal Tourism in Lombok Island, West Nusa Tenggara}

\section{Main Potentials: Natural Resources and Culture}

The natural resources and culture here mean the geographical condition of West Nusa Tenggara in general and Lombok, in particular, that is beautiful and natural. First is the beach, one of the sharia tourism potentials in Lombok. Although many beaches are found in Indonesia, the beaches in Lombok have uniqueness. They are clean and have white sand with beautiful scenery. They are located in the Western, Central, Northern, and Eastern part of Lombok, such as Sekotong beach in Lobar, Kuta and Mawun beaches in Loteng, and Pink and Surga beaches in East 
Lombok (Observation, June 23, 2017). Next, when explored further, Lombok Island also has white sand and beautiful waves that stretch more than $6 \mathrm{KM}$ in the West to North. This condition provides an inviting atmosphere for those who love water sports, such as surfing and so on (Observation, July 5, 2017).

Second is small islands popularly known as Gili. Lombok has several small islands that stretch both in the West and East, Gili Nanggu, Gili Sudak, Gili Tangkong located in Sekotong of West Lombok, Gili Meno, Gili Air, and Gili Trawangan in North Lombok. All of these islands provide beautiful sea views with relatively small waves for those who are fond of areas with calm waves for diving and other beach activities (Observation, July $5,2017)$. In addition to the beaches and seas mentioned above, Lombok is also famous for some beautiful hilly areas accompanied by mountains. One of the famous mountains is Mount Rinjani, one of active volcanos in Indonesia and of favorite tourist destinations for both local and foreign tourists (Observation, July 5, 2017).

Third deals with a unique and attractive culture in Lombok. Lombok is a plural island though it is dominated by Muslim communities. People live safely, comfortably, and peacefully. In Lombok are many historical relics, such as the ancient mosques built in the $16^{\text {th }}$ and $17^{\text {th }}$ centuries. Some mosques are more than hundreds of years old like the mosques in Pujut Lombok Tengah and Masjid Kuno Bayan. Besides, the island also has unique local arts, games, and musical traditions different from other places (Observation, July 5, 2017). Among the traditions or cultures of the Sasak-Lombok community which is the only one in the world is the Topat War, a war that shows a symbol of peace between two religions, i.e. Islam and Hinduism in Lingsar, West Lombok, West Nusa Tenggara. 


\section{Supporting Potentials}

In addition to the natural resources and culture described above, other potentials (see Kelana 2016) for developing halal tourism in Lombok include (1) local government support, (2) hospitality of the Sasak-Lombok community, (3) accessibility to tourist destinations, (4) closeness to Bali Island, and (5) religiosity of the Sasak community.

The first potency deals with support from local and national governments. The potential for halal tourism in Lombok can also be seen from government support. Among the national and local government support is the support of the National Sharia Council (DSN) and the NTB Governor through halal tourism regulation, i.e. the NTB Governor Regulation of 2015. The National Sharia Council for a fatwa, for example, issued a guideline for organizing tourism based on sharia principles. The guideline states that tourism is a travel activity carried out by a person or group of people by visiting certain places for recreational purposes, personal development, or learning the uniqueness of the tourist attractions in a temporary period. Sharia tourism is a tourism that is in accordance with sharia principles. Tourism is a variety of leisure activities and is supported by various facilities and services provided by the community, business people, and government. Sharia tourist destinations are geographical areas within one or more administrative regions in which there are tourist attractions, religious and public facilities, tourism facilities, accessibility, and communities that are interrelated and complement the realization of tourism in accordance with sharia principles (MUI 2016).

Among the principles is the avoidance of polytheism, immorality, danger, tabdhīr or isrāf, and evil; the making of benefits, both materially and spiritually (MUI 2016). Furthermore, in the NTB Governor Regulation of 2015 concerning halal tourism, Article 2 Paragraph I, it is stated that the purpose of halal tour- 
ism regulation is to provide security and convenience of services to tourists. Therefore, they can enjoy safe and halal tourist visits as well as obtain ease of travel. What is quite interesting is about Article 8 on spa, sauna, and griya pijat (massage center) that states that every spa, sauna, and griya pijat should provide treatment rooms for men and women separated. They should also give a couple of room or suite room used explicitly for husband and wife. They should also offer mind therapy and physical therapy that do not lead to polytheism and pornography; male therapists for men, and female therapists for women; and facilities that make it easy to pray (the NTB Governor Regulation Number 51 of 2015). This fact is both interesting and challenging for the development of halal tourism in Lombok of West Nusa Tenggara.

The second concerns the familiarity of the Sasak people with hospitality and tolerance. People of Lombok are known as a tolerant community that likes to help other communities. This attitude is in accordance with the philosophy of the word Lombok itself, which means straight. If a problem happens, it is usually related to a person or a few people, not the Sasak-Lombok community in general. They believe that the guests are the kings who are highly valued by the Sasak people. From several observations, it is clear that people in the Sasak villages of Lombok highly respected their guests. Almost every guest, both poor and rich, is willing to come to houses for the hosts will serve their guests, at least with coffee and small dishes. It is found that if a guest visits the Sasak community house for five times, then the guest will get the coffee five times. Hospitality and generosity are the main characteristic of the Sasak-Lombok community. Zakaria said:

"People of Sasak-Lombok are a community known with their tolerance since their ancestors; they hold the philosophy of $r e$ ciprocation of value saying that those who respect the others 
would be respected. This seems to be the accepted translation of the hadith stating: love those on the Earth, so that those in the sky will love you." (Zakaria, Interview 23 July 2018).

Many tourists from Europe and the Middle East who walk around the tourist area are enthusiastic to just say hello in a modest language like hello mister or miss or simply assalamu'alaikum to greet the local people.

The third is about accessibility to tourist destinations in Lombok. To reach Lombok, tourists can use air or sea transportations. An interview with Sarapudin found that, from the west, people could cross from Padang Bai. From the East, they can pass from Sumbawa to Labuan Kayangan (Sarapudin, Interview August 23, 2018). Husnaein, one of the residents in Pemenang of North Lombok informed that one alternative route if the tourists do not want to go by sea is that they take the Bali route to the three Gilis (Meno, Water and Terawangan) because there is a special route from Bali to the three Gilis (Husnaen, Interview 24 August 2017). In addition to the land route, there is also the air route in the Lombok International Airport. All the ways provide easy access for the tourists who want to visit Lombok. There is no difficulty to travel to Lombok of West Nusa Tenggara.

The fourth is related to Lombok's neighbour, i.e. Bali. According to Abdul Majid, one of the heads of the Tourism Awareness Group (Kelompok Sadar Wisata or Pokdarwis), the next potential of Lombok is its relative distance to Bali. The tourists-especially those from the Middle East-after visiting Bali can also come to Lombok, and vice versa. Hence, these two places (Bali and Lombok) are mutually beneficial because both of them are known as the tourism areas (Majid, Interview 24 July, 2018).

\section{The Challenges of Developing Halal Tourism in Lombok}

Conceptual Challenge 
The conceptual challenge of developing halal tourism in Lombok is presented in table 1 .

$$
\begin{gathered}
\text { Table } 1 \\
\begin{array}{c}
\text { Multipersception of the concept of Sharia tourism in Sasak commu- } \\
\text { nity of Lombok }
\end{array}
\end{gathered}
$$

\begin{tabular}{|c|c|c|}
\hline No & $\begin{array}{l}\text { The Different Concepts of } \\
\text { Sharia Tourism }\end{array}$ & Implication \\
\hline 1 & $\begin{array}{l}\text { Sharia tourism is the same } \\
\text { as halal tourism }\end{array}$ & Both are often used interchangeably \\
\hline 2 & $\begin{array}{l}\text { Sharia tourism is not } \\
\text { necessarily Muslim-Friendly } \\
\text { tourism }\end{array}$ & $\begin{array}{l}\text { The term proposed was, then, Muslim } \\
\text { Halal-Friendly Tourism }\end{array}$ \\
\hline 3 & $\begin{array}{l}\text { Halal tourism means halal } \\
\text { in terms of food and drinks }\end{array}$ & $\begin{array}{l}\text { This concept is constructed by the } \\
\text { tradition of Lombok's Sasak people } \\
\text { predominantly Muslim }\end{array}$ \\
\hline 4 & $\begin{array}{l}\text { Sharia tourism is a term } \\
\text { that is not inclusive }\end{array}$ & $\begin{array}{l}\text { Sharia tourism gives the impression of } \\
\text { Islamization or arabization which may } \\
\text { lead to islamophobia }\end{array}$ \\
\hline 5 & $\begin{array}{l}\text { Sharia tourism disrupts } \\
\text { conventional tourism }\end{array}$ & $\begin{array}{l}\text { Sharia tourism is considered contrary to } \\
\text { conventional tourism whereas the former } \\
\text { is an alternative to the latter }\end{array}$ \\
\hline 6 & $\begin{array}{l}\text { Sharia tourism is perceived } \\
\text { as the antonym of haram } \\
\text { tourism (prohibited } \\
\text { tourism) }\end{array}$ & $\begin{array}{l}\text { Halal tourism is not confronted with } \\
\text { haram tourism but an alternative to } \\
\text { service excellences, additional service, and } \\
\text { optional service for Muslim guests who } \\
\text { want safety and security }\end{array}$ \\
\hline 7 & $\begin{array}{l}\text { There is no halal tourism, } \\
\text { but religious tourism }\end{array}$ & $\begin{array}{l}\text { There is an assumption that tourism is } \\
\text { identical with entertainment, and putting } \\
\text { the word sharia into tourism is an } \\
\text { artificial thing }\end{array}$ \\
\hline 8 & $\begin{array}{l}\text { Ethical tourism is seen } \\
\text { better }\end{array}$ & $\begin{array}{l}\text { Tourism should prioritize the sapta } \\
\text { pesona wisata, be more inclusive, not lead } \\
\text { to Arabization and Islamization causing } \\
\text { islamophobia }\end{array}$ \\
\hline
\end{tabular}

Based on table 1, it is visible that the realization of sharia tourism in Lombok faces complexity because of different concepts perceived by the government, local people, and tourism actors. Details of the concepts will be explained as follows:

a. Contestation of the ideal concept for halal tourism

The first conceptual challenge is the contestation between 
halal tourism and Muslim-Friendly Tourism (MFT). According to Zakaria Ansari (Interview June 26, 2018), when a tourist destination is categorized as a halal destination, all facilities must be prepared for Muslims. However, something that has been categorized as part of halal tourism does not automatically make the place comfortable. Therefore, it must be distinguished between halal tourism and Muslim-Friendly tourism. Another statement by Jumarim said:

“... halal tourism should not be sufficiently understood as tourism whose destiny is related to Islam. When an Indonesian Muslim or Middle Eastern Muslim comes to Borobudur Temple in Magelang, for example, he comes there to witness the beauty and privilege of God's creation to increase his faith in God the Almighty. Of course, everyone is aware that the tourist destination was built by Hindus. Is the tourism, then, considered as haram tourism or halal tourism? In my opinion, that could be part of halal tourism. Therefore, it must be emphasized that a place may not be certified as a halal destination, but that place is a place that can increase faith in God, so it can be called halal tourism or halal travel." (Jumarim, Interview June 23, 2018).

From the above argument, it appears that halal tourism is understood more broadly than the definition that developed among people. Some of them, for example, said that halal tourism is a tourist visit activity whose destinations provide tourism product, service, and management facilities that meet the sharia elements (Jumarim, Interview 24 June 2018). Meanwhile, $\mathrm{N}$. K. Gabdrakhmanov $(2016,88)$ stated that "halal tourism and recreation is a type of tourism aimed at Muslims, providing an opportunity to rest in accordance with the rules of Islam”.

The second conceptual challenge is the contestation between halal tourism and Islamic Tourism. Islamic tourism is defined as any activity, event or experience carried out for travel that is in accordance with Islamic teachings. According to Sarapu- 
din (Interview June 24, 2018), there is no difference between halal tourism and Islamic tourism because both refer to Islamic teachings. In this regard, Jumarin stated that the problem often occurring when tourism is associated with sharia (then the term halal tourism and sharia tourism appear) is a matter of tradition and accentuation. In the context of tradition, Lombok in particular and Indonesia in general, the word halal is more associated with food and drinks. At the same time, Islamic tourism is more identical to everything that is determined in accordance with the teachings of Islam, which is usually known by the word sharia. Here, Islamic tourism is synonymous with halal tourism. This concept is also used in Malaysia because Islamic tourism is defined as any activity, event, and experience undertaken in a state of travel that is in accordance with Islam (Islamic Tourism Center 2019).

Furthermore, there is an interesting statement by Riyanto, a resident of the Golong community saying that:

"Halal tourism (or Islamic tourism) has been a subject of debate because the term is always linked with all activities that are in accordance with Islamic teachings. This definition creates a problem when it is associated with halal money. Halal money in the tourism context is concerned with where the money was obtained from and for what purpose it is used. Most of the hotels or other tourist facilities in Lombok, such as homestays, inns, and bungalows located in Lombok are mostly owned by non-Muslims. In my opinion, what is important in tourism, whoever it belongs to, is the tourism service that is Islamic, so that tourism can be considered halal tourism. In Japan, for example, there is also halal tourism, and so on." (Interview June 25, 2018).

In connection with Riyanto's statement above, Busyairy questioned whether or not there is a guarantee that money used for tourist destination facilities or used by lodging owners is obtained in an Islamic way. Therefore, in this context, the concept 
of halal or Islamic tourism needs to be further discussed, or at least there must be two definitions of halal tourism, namely inclusive and exclusive definitions (June 25, 2018).

The next term deals with Muslim-Friendly tourism. In this sense, a Muslim-Friendly Tourist is understood as a Muslim traveller who does not want to compromise their faith-based needs with anything that is not in accordance with Islamic teachings while travelling. He always associates his needs with the concept of halal (Comcec 2016, 10). Sarapudin (Interview June 24, 2018) stated that in accordance with the name, Muslim-Friendly tourism emphasizes something that is lawful and provides safety simultaneously, because not everything lawful provides safety. Sarapudin argued that when a hotel in Senggigi of West Lombok had received a halal certificate by the national certification board as a halal hotel destination, the hotel was surrounded by noise from karaoke clubs in the Senggigi area. Therefore, the word halal and safety are of equal importance. What was stated by Sarapudin is interesting to analyze because, conceptually, a hotel that has been certified as a halal hotel, should meet all requirements of the Islamic law (sharia).

b. Perception of halal tourism as halal in food, drink, and cosmetics

Many Sasak-Lombok people believe that halal tourism is identical with halal in terms of food, beverage, and cosmetics. One of the sellers in Cakra, when asked about halal tourism, said that: halal tourism is a tourism that provides halal foods, so I do not sell foods that are haram (forbidden) including the ingredients, like the bakso I sell is made from cows and chickens"(Sukim, Intereview 23 July, 2018). Such a view might have been influenced by his education background that probably does not reach the high school or bachelor (S1) levels. However, it turned out that a similar view was shared by people with an S1 degree. A seller named Hurnain, for example, said: 
"As I know, halal tourism must be related to halal in food and drinks. There are many halal labels on packages or cans of food and drink. I'm not sure if it is also related to hotels, spas, massages, and so on. Only one or two can implement such criteria, maybe. Tourism is more synonymous with entertainment and pleasure. Therefore, if you want to worship, then just stay at home (while laughing).” (Interview July 7, 2018).

What stated above shows that there are still many Sasak people who do not understand what halal tourism means. In this case, Bahardeen offers what so-called faith-based need is. According to him, there are six (6) faith-based needs, namely halal food, Salaah (Prayer), water-usage friendly toilets, Ramadan services and facilities, facilities with no non-halal activities and recreational facilities with privacy (Comcec 2016, 2).

c. From halal tourism to ethical tourism

It is a fact that, for some people, halal tourism and conventional tourism do not have any difference. Majid, one of the leaders of the tourism community in Sekotong, said, "I will agree if halal tourism or sharia tourism is renamed with ethical tourism because this term seems more inclusive. Ethical tourism is more appropriate to replace the term sharia tourism or halal tourism as it has the same mission as sharia tourism and promotes the sapta pesona, including safety, comfort, hospitality, and so on.". Furthermore, Majid stated, "Ethical tourism is found, for example, when tour guides come to a tourist destination and greet guests, many of the guides immediately say, "What is your name?", "Where do you come from?", etc. These expressions are not wrong, but it is better if they start first with small talk like, "Excuse me, what can I do for you?", or at least give a smile and say hello (smile before addressing). This way, a tour guide will not only be understood as a coin pursuer but also an agent of politeness, friendliness, and comfort (Majid, Interview 24 July 2018).” 
d. Perception of halal tourism as a disturbing concept

The next conceptual challenge deals with a perception stating that halal tourism is a disturbing concept. Many people think that halal or sharia tourism is tourism that does not respect differences. Hurnain, one of the informants, stated, "Whatever the reason, the word sharia or halal is more nuanced in Islam and tends to be exclusive, while it is known that Lombok is a plural society though Islam is a religion with dominant followers." (Hurnain, Interview 7 July 2018).

Unlike the above statement, Mukhtar maintains that when viewed from a religious perspective, the term comes from Islamic teaching. Still, substantively it has an inclusive meaning, i.e. the benefit aspect. In this context, halal tourism emphasizes comfort for the tourists, especially those from the Middle East. An analogy between halal tourism and conventional tourism can be made. Halal tourism is like a ring on the middle finger, and conventional tourism is like a ring on the little finger. While the ring on the middle finger can go to the little finger, the ring on the little finger may not necessarily get into the middle finger (Mukhtar, Interview July 20, 2018). The two are close together. In this sense, the realization of the halal tourism will be successful if the community, including the tourism actors, understands the relationship between the two types of tourism; that is, the realization of halal tourism is also beneficial to conventional tourism. Nevertheless, the latter is not necessarily beneficial to the former.

e. Perception of halal tourism as Arabization and Islamization

Perception of halal tourism among the Sasak-Lombok community as Arabization and Islamization also becomes an essential conceptual challenge. This perception is not only from Muslims, but also from non-Muslims. As stated by Adi, a resident of Suranadi, halal tourism gives the impression of Arabization and 
Islamization. What I mean by Arabization is to bring the Middle Eastern model into the concept of Lombok tourism. In contrast, Islamization leads to the impression that the existing tourism is un-Islamic so that it needs to be Islamized. This seems to be the reason why conventional tourism actors go away (Adi, Interview 6 July 2018).

\section{f. Confronting halal tourism with haram tourism}

Many people in the community also see halal tourism or sharia tourism as the opposite of haram tourism; halal is antonymous with haram. Thus, the presence of halal tourism is thought to indirectly consider the existing tourism as haram tourism, whereas the former should play a complementary role to conventional tourism. In this case, Taufan Rahmadi stated that halal tourism is an alternative to conventional tourism. It provides service excellence for tourists who want to get better service (Rahmadi, Interview July 23, 2018).

Halal tourism is not necessarily owned by Muslims. It could be owned by non-Muslims while workers and services are presented in a way accepted by Islamic law. A swimming pool in Suranadi, for instance, is owned by a Hindus. Nevertheless, the pool is divided into two parts, i.e. one part for men, and another for women. Moreover, the owner employs Muslim women wearing hijab or veil (Observation, 23 August 2018). The same view can be found in the Suranadi tourist complex, which is full of Hindu temples. There, the sellers of Sate Bulayak are the Muslims coming from Lembuak Narmada (observation, $23 \mathrm{Au}-$ gust 2018). Likewise, many Muslim tourists visit Pura Lingsar, the most historic temple in Lombok Island. If they want to enjoy local dishes, then the area around the temple is selling halal food, because the sellers are the Muslim residents around Lingsar. (Observation, July 23, 2018). 


\section{Practical Challenges of Developing Halal Tourism in Lombok}

\section{Economic Challenges}

This economic challenge emerges due to the many guests in the region. The term "guests" is metaphorical since they act as a visitor in their own homes. In one hand, halal tourism can have a positive impact on the people of Lombok, such as on the increasing government revenue and job opportunities. P. Rajka Presbury and Deborah Edwards stated that "local employment can be low-level or unskilled, seasonal, low-wage, part-time with little opportunity for advancement" (Presbury and Edwards 2010, 50). In the other hand, however, halal tourism also brings negative impacts economically. For example, the prices of goods and services around the tourism area are rising. Later, local communities are also competing to sell their land to investors, so that later when the investors have built tourist destinations, then people of the local community might be asked to become a guard on the land they used to have (Fariana 2016). This situation makes them look like a guest in their own homes. Finally, unskilled local workers help create competitive salaries.

Andi Bayan stated that, economically, local people have benefited from tourism. However, they fill the marginal sides such as by selling ice, packaged rice, tire, and so on. They do not own hotels, spa, bungalows, karaoke, minimarkets, and so on. This economic problem creates a wide gap between the rich and the poor, between the local communities and the migrant communities or wealthy investors (Bayan, Interview June 23, 2018). Based on observations, new halal tourist destinations in Senggigi, Pantai Kuta of Central Lombok, Gili Air, Menu, and Gili Trawangan will be built. There, it is obvious that the local people remain in marginal positions (Husnen, Interview June 23, 2018).

In addition, Majid, the head of the Pokdarwis Sekotong, informed that the economic problem also occurred among the 
businessmen. In Sekotong, according to him, if people want to cross to Gili Nangu or Gili Tangkong, they have many options concerning the ports. However, the businessmen do not give the same tariff; some require 300 thousand, and some other 250 thousand. They also say negative things about their competitors (Majid, Interview 23 July 2018). In addition, Majid explained that, in terms of travel management, a term called red plate port is used to refer to the government business, while black plate port is the private-owned property. However, the red plate port usually loses in the competition due to the mushrooming ports for tourism (Majid, 26 June 2018). In fact, from an economic perspective, tourism must be able to "stimulates local production contributing to household incomes and standards of living" (Presbury and Edwards 2010, 50).

\section{Environmental Challenge}

The practical challenge of developing halal tourism in Lombok deals with a halal view. Husnain stated that the challenge of halal tourism is related to not only nature and culture, but also halal perspective. When people go to Suranadi Tourism Park in Narmada sub-district, for example, they will see the view of dogs roaming around and tuak (liquor) sellers along the road to and from Suranadi. This condition will disturb the Middle Eastern people who think that both dog and tuak are haram or forbidden and najis or unclean (Observation, May 5, 2018).

One of the Suranadi residents, Adi (Interview 2 May 2018) stated that it is hard to blame those who sell tuak or liquor because it is part of the community's income even though the area is considered part of the halal tourist destination. In addition, in the halal tourist areas are many inns or lodges where prostitution exists. Therefore, in term of environmental aspect, there must be a meeting point between the local community and the government in order to develop the halal tourism. Indeed, one 
of the impacts of tourism that needs to be anticipated is about increased prostitution, drug-taking, and crime (Presbury and Edwards 2010, 50).

\section{Social and Ethical Challenge}

The practical challenge of developing halal tourism also deals with efforts to dispel the social perception that Senggigi as one of the most popular tourist destinations in Lombok is identical to $3 \mathrm{~S}$, namely sea, sun and sex. People of the local community even say that many Muslims are more afraid of pigs than God; that is, when someone goes to a hotel, and he is offered pork, it will be easy for him to refuse. However, when he is provided a "living blanket" or sexual affair, not a few of them want to. Some even book the living blanket on purpose (Interview with AR, Hotel Security in Mataram, June 15, 2018).

Indeed, one of the most popular tourist destinations for halal tourism is Senggigi (Nararya and Pranggono 2016). There are bars, karaoke, pubs, and other types of nightlife. Noise is a common thing. With this in mind, safety, comfort, calmness, and coolness for tourists become interesting to investigate. As the most popular tourist area in Lombok, both domestic and foreign tourists are part of every-day life in Senggigi. In this case, the label attributed to Lombok Island of a thousand mosques is being challenged with $3 S$ culture, namely sea, sun, and sex. Here, the term sea refers to the position of Senggigi, which is near the beach and even touches the shoreline and is decorated with clean white sand. The term sun refers to the beautiful Senggigi beach where tourists can sunbathe under the sunburn and wear a naked dress that breaks the sharia corridor. Finally, the term sex refers to prostitution which reality is difficult to accept theologically. The prostitution seems to be inseparable from the social existence in in certain areas at Lombok because it encompasses the economy, lifestyle, permissivism, hedonism, apathism, and others (Suprapto, Interview April 26, 2018). 
Halal tourism does not mean halalism; that is, it should not make something that is not halal as halal. A common saying by the local community known as STMJ (Susu, Telor, Madu, and Jahe; Milk, Egg, Honey, and Ginger) should not be interpreted as Shalat Terus, Maksiat Jalan (keep on praying, keep on immoral deeds) but transformed into Shalat Tetap, Maksiat Jaubi (keep on praying, and avoid immoral deeds), because the substance of prayer is not restricted to the vertical dimension to God but also the social dimension to fellow humans. Hence, STMJ can also mean Shariah Terlaksana, Maslahah Jiwanya (when sharia is well implemented, it will bring goodness to the soul. In line with this notion, the West Nusa Tenggara Governor Regulation Article 2 Paragraph 1 states that the purpose of halal tourism is to provide security and comfort of services to the tourists, so that they may enjoy their visits safely, lawfully (halal), and easily.

\section{Cultural Challenge}

Another challenge for halal tourism in Lombok is related to technology and culture. Here, locality and originality become the key terms in tourism development. Both terms refer to the authenticity of the local community and the taste of the tourists. According to Majid, the challenge in the tourist destination development is concerned with how to maintain the authenticity of the local culture, not how to adjust the local culture to the taste of the tourists. In this sense, authenticity of the local culture should be able to attract the tourists (Majid, 5 June, 2018).

Regarding this challenge, Deborah argued that commodification could turn local cultures into commodities when religious rituals, traditional ethnic rites and festivals are reduced, sanitised and performed on-demand to conform to tourist expectations (Presbury and Edwards 2010, 50). While Deborah concerns the commodification, Andi uses commercialization to see the challenge. He stated that one of the biggest problems in 
tourism development in general or halal tourism, in particular, is how to develop tourist areas that can adjust to the taste of the tourists while maintaining the authenticity of the local culture. The local tradition should not be sacrificed for the sake of the taste of the tourists.

\section{Islamic Education in Promoting a New Perspective on Strategic Management}

Islamic education has a strategic role in realizing halal tourism in Lombok. In this context, the researcher uses the concept of Islamic education proposed by Muhaimin. According to him, Islamic education can be seen at least in three aspects: (1) Islamic education as a value, (2) Islamic education as an activity, and (3) Islamic education as an institution. This concept implies that Islamic education is composed of Islamic values and systemic activities involving teachers, students, curriculum, methods, environment, and objectives organized in an institution named Islamic educational institution (Muhaimin 2011, 21).

As an institution, Islamic education requires one perspective -strategic management- to develop halal tourism in Lombok in accordance with expectations. Strategic management is the management used to determine strategic plans. It can be done by analyzing (1) where we are, (2) where we want to go, and (3) how to get there (Wahab 2013, 45). For the first question, the answer is Lombok with its current status as the halal tourist destination. For the second question, the answer is a better service to develop halal tourism. Finally, for the third question, the answer is by deciding strategic plans. In this regard, something must be involved in every stage of strategic planning. It is here that Islamic education institution finds its essential role.

A simple step in the strategic management for an Islamic educational institution in Lombok is to conduct an Internal Environmental Analysis focusing on strengths and weaknesses and 
an External Environmental Analysis focusing opportunities and threats. From the two analyses, it is obvious that:

First, regarding the strengths, the potentials for halal tourism in Lombok NTB appears in (1) the status of Lombok as the world best halal tourism destination and world best halal honeymoon destination, (2) the support from the religious community of Lombok, (3) the support from the provincial government, e.g. the West Nusa Tenggara Governor Regulation No. 2015, (4) the natural resources of West Nusa Tenggara in general and Lombok in particular that are beautiful and natural, (5) the tolerant Lombok community that are popular with their reciprocation of value, i.e. respect for people if you want to be respected which is the translation of love those on the earth, those in the sky will love you, (6) the cultural resources with reference to the plural society of Lombok, (7) the reachable prices, (8) the accessibility to and from Lombok, and (9) the Lombok's geographical location which is close to Bali.

Second, regarding the weaknesses, several things appear. (1) Halal tourism in Lombok still has less human resources. (2) Some locations are still comfortable with conventional concepts of tourism and are worried about decreasing profits when halal tourism is applied. (3) The concept of halal tourism has not been well communicated to cause a lack of understanding, misunderstanding, multi-interpretation, and even paranoid.

Third, regarding the opportunities, they include: (1) the national and international reputation of Lombok as a halal tourist destination, (2) the location of Lombok that is close to Bali, (3) the support from the central government through Permen Parekraf on tourism, (4) the rapid development of technology as a media for promotion, cooperation, and others, and (7) the support from the Central MUI through the National Sharia Council.

Fourth, regarding the threats, they include: (1) the infiltration of negative foreign cultures, especially with the free-market 
era, (2) the misuse of internet in social media, such as Facebook, Twitter, Instagram etc., by falsifying real identities that may lead to unpleasant issues and disturb the security and comfort, (3) the security when entering Lombok, especially through ports, (4) the presence of trans-national ideology that is rigid, radical, and anti-tourism.

Based on the above-mentioned description, the role of Islamic education in Lombok in particular is: (1) to prepare an Islamic university that focuses on the development of halal tourism, (2) to prepare a department in the university that develops halal tourism, (3) to prepare a curriculum and courses in the university that include halal tourism, (4) for the existing Islamic higher education to collaborate with tourism actors or Pokdarwis to develop halal tourism through LPM or LP2M in each institution. Therefore, Islamic education may help contribute (1) in disseminating the concept of halal tourism to be comprehensively understood by the Sasak-Lombok community of West Nusa Tenggara, (2) in reconciling the perspective of society and government concerning tourism, (3) ) in clarifying the misunderstood concepts about halal tourism, and (4) in explaining that halal tourism is not intended to kill conventional tourism; in fact, it is beneficial to the whole community of Lombok and even Indonesia.

\section{Conclusion}

Although Lombok has high potentials in developing halal tourism since the region is supported by its natural and non-natural resources, challenges do exist. Indeed, the challenges are related to not only conceptual matters but also practical matters. The conceptual issues are concerned with the different perceptions between the Sasak-Lombok community and the government about halal tourism. For some people in Lombok, halal tourism is an exclusive term and may disrupt conventional tour- 
ism. They, then, propose a new term known as ethical tourism.

Meanwhile, practical matters are related to economic, environmental, social, and cultural challenges. Despite all obstacles, however, halal tourism does offer a positive side, i.e. comfort. Therefore, the role of Islamic education in Lombok is significant in developing the halal tourism. Such a role can be realized by preparing a department, curriculum, or courses in Islamic higher education that focus on halal tourism. The Islamic education may also help explain the community that halal tourism is not an exclusive tourism, nor is it intended to harm conventional tourism. It is an alternative in the tourism development to promote better service to the tourists. The role of Islamic education is most likely to bring success if it can formulate strategic management by conducting an internal environmental analysis focusing on strengths and weaknesses and an external environmental analysis focusing on opportunities and threats.

\section{Bibliography}

Andrinata, Sumarmi, and I Komang Astina. 2016. "Pengembangan Modul Geografi Pariwisata Berbasis Paket Wisata Pulau Lombok." Jurnal Pendidikan: Teori, Penelitian, Dan Pengembangan 1 (10): 1999-2003. https://doi. org/10.17977/JP.V1I10.7339.

Arikunto, Suharsimi. 2010. Prosedur Penelitian: Suatu Pendekatan Praktik. Jakarta: Rineka Cipta.

Battour, Mohamed, and Mohd Nazari Ismail. 2016. "Halal Tourism: Concepts, Practises, Challenges and Uture." Tourism Management Perspectives 19 (July): 150-54. https://doi. org/10.1016/j.tmp.2015.12.008.

Comcec. 2016. "Muslim Friendly Tourism (MFT): Understanding the Supply and Demand Sides In the OIC Member Countries." In Proceedings Of The 7th Meeting Of The Comcec Tourism Working Group. Ankara, Turkey: Com- 
mittee for Economic Commercial Cooperation Of the Organization of Islamic Corporation.

Duman, Teoman. 2011. "Value of Islamic Tourism Offering: Perspectives from the Turkish Experience." In World Islamic Tourism Forum (WITF 2011). Kuala Lumpur.

Fariana, Andi. 2016. "Hukum Islam Sebagai the Living Law Dalam Meminimalisasi Dampak Negatif Pariwisata Di Pulau Lombok Bagian Utara." Istinbath: Jurnal Hukum Islam 15 (2): 236-54.

Firdausi, Izza, Stanijuanita Marantika, Zein Nidaulhaq Firdaus, and Rifqah Sajidah. 2017. "Lombok: Halal Tourism as a New Indonesia Tourism Strategy." In The 4th International Conference on Humanities, Social Sciences and Education (ICHSSE-17). Dubai UAE.

Fitriani, Iwan. 2015. "Strategi Pengembangan Wisata Halal Di Pulau Lombok.” In Seminar Nasional Asosiasi Dosen Indonesia (ADI). Lombok.

Gabdrakhmanov, N K, M V Rozhko, and L V Khafizova. 2016. "Problems of Development of Halal Tourism in Russia." Journal of Organizational Culture, Communications and Conflict 20 (2): 88-93.

Hatch, J. Amos. 2002. Doing Qualitative Research in Education Settings. New York: State University of New York Press.

Islamic Tourism Center. 2019. "Discover the Muslim-Friendly Malaysia.” Itc.Gov.My. 2019. https://doi.org/https://itc. gov.my/tourists/discover-the-muslim-friendly-malaysia/.

Jaelani, Aan. 2017. "Halal Tourism Industry in Indonesia: Potential and Prospects." Munich Personal RePEc Archive, no. 76235 .

Kelana, Irwan. 2016. "Menggali Potensi Wisata Halal Di Lombok.” Republika.Co.Id. 2016. https://www.republika. 
MOHAMAD IWAN FITRIANI, NAZAR NAAMY

co.id/berita/nasional/daerah/17/06/28/dunia-islam/mozaik/16/08/01/ob7i3x336-menggali-potensi-wisata-halal-di-lombok.

Moleong, Lexy J. 2006. Metodologi Penelitian Kualitatif. PT. Remaja Rosda Karya. https://doi.org/10.1016/j.carbpol.2013.02.055.

Muhaimin. 2011. Pemikiran Dan Aktualisasi Pengembangan Pendidikan Islam. Jakarta: Rajawali Pers.

MUI. 2016. "Fatwa Dewan Syariah Nasional Majelis Ulama Indonesia No: 1 08/Dsn-Mui.X12 Tentang Pedoman Penyelenggaraan Pariwisata Berdasarkan Prinsip Syariah.” Jakarta: Majelis Ulama Indonesia.

Nararya, Arina Gita, and Bambang Pranggono. 2016. “The Development Strategy of Syariah Tourism on Tourism Routes of Senggigi Beach, Lombok Island Nusa Tenggara Barat.” Prosiding Perencanaan Wilayah Dan Kota 2 (2).

Presbury, Rajka, and Deborah Edwards. 2010. "Sustainable Operations Management." In Understanding the Sustainable Development of Tourism. Oxford: Goodfellow Publishers Limited.

Puangniyom, Piyachat, Nantawan Swangcheng, and Tosaporn Mahamud. 2010. "Halal Tourism Strategy to Promote Sustainable Cultural Tourism in Thailand." In CEBU International Conference on Studies in Arts, Social Sciences and Humanities (SASSH-17). Cebu.

Putra, Errid Hadisyah, Sri Rahayu Hijrah Hati, and Sri Daryanti. 2016. "Understanding Muslim Customer Satisfaction with Halal Destinations: The Effects of Traditional and Islamic Values." In BE-Ci 2016: 3 Rd International Conference on Business and Economics. https://doi.org/10.15405/ epsbs.2016.11.02.16.

Rahardjo, Mudjia. 2013. "Mengenal Lebih Jauh Tentang Studi 
Kasus.” Malang: Universitas Islam Negeri Malang.

Shaufi, Ahmad. 2015. "Sustainable Tourism Master Plan for Lombok 2015-2019.” In Executive Summary Badan Perencanaan Dan Pembangunan Daerah Provinsi Nusa Tenggara Barat. Lombok: Bapeda.

Sulhaini, Akhmad Saufi, and Rusdan. 2015. "Developing Halal Tourist Destination: Investigating Lombok's Potentials from Destination Marketing Perspective.” In The Tourism Outlook, Balancing Development and Sustainability in Tourism Destinations. Springer.

Wahab, Solichin Abdul. 2013. "Materi Manajemen Stratejik Program Doktor MPI.” Malang: Universitas Islam Negeri Malang. 
This page intentionally left blank 